\title{
$550 \mathrm{kV}$ シャントリアクトル電流遮断時の再発弧と
}

\section{高周波消弧現象}

\begin{tabular}{|c|c|c|c|c|c|c|}
\hline 正負 & 阎部成光 & (東京電力株式会社) & 正員 & 向賞政典 & （東京電力杭 & 栻会社) \\
\hline 正 & 腰塚 正 & （株式会社 東芝） & 正員 & 新海 健 & （株式会社 & 東芝) \\
\hline & 西脇 進 & （株式会社 東芝） & 正䝿 & 三宅倍之 & 三社 & 東芝) \\
\hline 正員 & 中本哲哉 & （株式会社 東芝） & 正負 & 才田敏之 & （株式会社 & 東芝) \\
\hline
\end{tabular}

Re-ignition Surge and High-Frequency Arc Extinction phenomena at $550 \mathrm{kV}$ Shunt Reactor Current Interruption

\author{
Shigemitsu Okabe, member (Tokyo Electric Power Co.) Masanori Koto, member (Tokyo Electric Power Co.) \\ Tadashi Koshizuka, member (Toshiba co.) \\ Susumu Nishiwaki, member (Toshiba co.) \\ Takeshi Shinkai, member (Toshiba co.) \\ Tetsuya Nakamoto, member (Toshiba co.) \\ Nobuyuki Miyake, member (Toshiba co.) \\ Toshiyuki Saida, member (Toshiba co.)
}

At the sub-station connected with transmission lines and cables, shunt reactors are sometimes installed to compensate the capacitive current of the transmission lines and cables. It is known that the re-ignitions occur and high-frequency currents flow during interrupting the shunt reactor currents by switches. When the high-frequency currents are interrupted immediately after the re-ignitions, called as high-frequency arc extinction, it of ten leads to appearance of repetitive re-ignitions or voltage escalations resulting in generation of dangerous over-voltages.

The authors investigated the occurrence of the high-frequency arc extinctions for a $550 \mathrm{kV}$ one-break SF6 gas circuit breaker during interrupting a $550 \mathrm{kV}$ shunt reactor current. By computations for a actual $500 \mathrm{kV}$ substation, minimum frequency of $290 \mathrm{kHz}$ was obtained for the high frequency current. However, it was found by conducting $550 \mathrm{kV}$ reactor current interruption tests that the high-frequency arc extinctions did not occur even if the high-frequency was lowered to $26 \mathrm{kHz}$. The high-frequency arc extinction is generally likely to occur at the lower frequency. So that it was concluded that the high-frequency arc extinction would not occur on the $550 \mathrm{kV}$ one-break SF6 gas circuit breaker during interrupting the shunt reactor current in the actual substations.

キーワード：シャントリアクトル遮断、再発弧サージ、高周波消弧、550kV一点切り遮断器

\section{1。まえがき}

長距離の送電線、ケーブルが接続される変電所では、そ の充電電流を補偵するため、シャントリアクトルが設置さ れる。シャントリアクトルは開閉器で多頻度で開閉される ことが多い。

シャントリアクトルを流れる電流を開閣器で遮断する 際に、開閉器が再発弧し、高周波電流が流れることが知ら れている。この高周波電流を開閉器がただちに遮断（高周 波消弧)してしまうと、多重再発弧、電压エスカレーショ ン等の現象に至り、機器の䋓縁に有害な過電圧が発生する 場合がある [1][2][3][4][5][6]。關閉器をシャントリアク トル遮断に適用する際、シャントリアクトルが設置される
回路および開閉器の特性を十分に調查しておく必要があ る。300kV 遮断器によるシャントリアクトル電流遮断の際 の再発弧と高周波消弧現象については、過去に筆者等の一 部が研究結果を報告した[2][3][4]。

本論文は、 $550 \mathrm{kV}$ 一点切りガス遮断器を $550 \mathrm{kV}$ シャント リアクトル電流遮断に適用するため、その高周波消弧特性 を調查した結果を述べたものである。まず、500kV 変電所 の例を模擬して、再発弧サージ計算を行った。実際の変電 所での再発弧の際の高周波電流の周波数等について調查 した。次に、この調查結果に基づいて、大電力試験場にお いて、リアクトル電流遮断試験を行った。短絡発電機を電

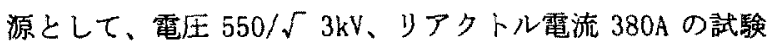
回路を構成した。遮断器の高周波消弧特性について、再発 
弧高周波電流の周波数を変えて測定した。最後に、実際の 変電所における高周波消弧発生の有無を評価した。

\section{2. リアクトル電流遮断時の再発弧現象}

シャントリアクトル電流遮断時の再発弧、高周波消弧現 象について説明する。図 1 は等価回路である。

シャントリアクトル電流は一般に小電流であるため、開 閉器は、十分に開極していなくても電流需点が来ると、こ こで電流を一旦遮断してしまう。しかし、極間距離が十分 に開雇していない状態で、リアクトル $\mathrm{L}_{\mathrm{I}}$ と静電容量 $\mathrm{C}_{\mathrm{i}}$ との

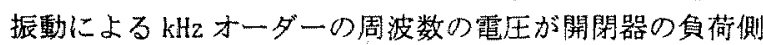
に現れるため、開閉器極間の絶緣が耐えられず、再発弧が 発生する場合がある。

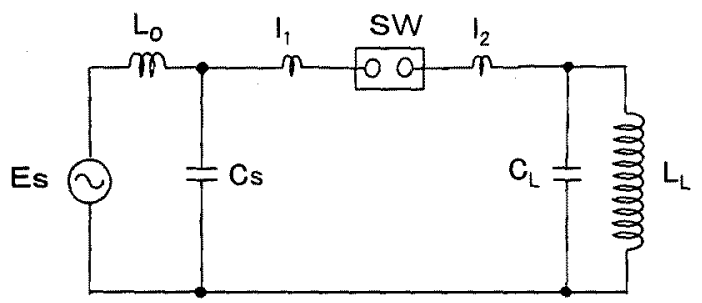

Es:電源、 L。:電源インダクタンス、SW: 開閉器

Cs:電源側キャパシタンス、 $\mathrm{C}_{\mathrm{L}}$ : 負荷側キャパシタンス

$\mathrm{I}_{1}$ : 電源側漂遊インダクタンス、 $\mathrm{l}_{2}$ : 負荷側漂遊インダクタンス

乚:負荷インダクタンス(シャントリアクトル)

図 1 シャントリアクトル電流遮断の等価回路

Fig. 1 Equivalent circuit of the shunt reactor current interruption

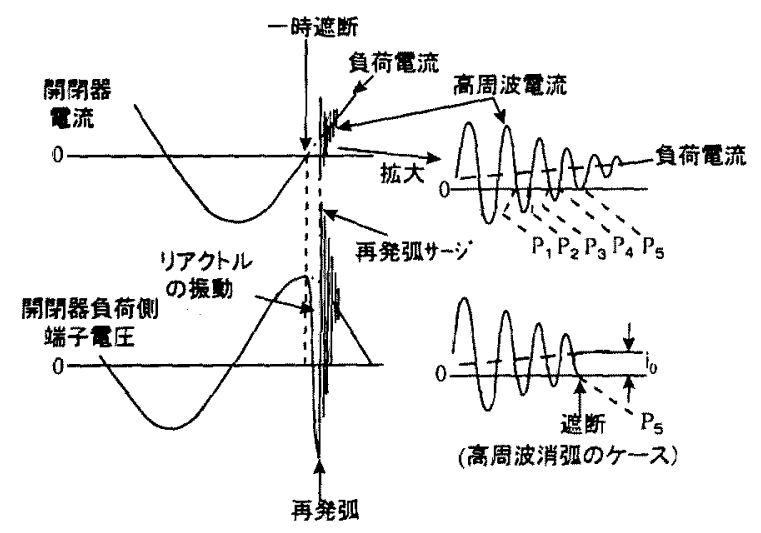

図 2 シャントリアクトル電流遮断時の再発弧と 高周波消弧の説明

Fig. 2 Explanation of re-ignition and highfrequency arc extinction during interrupting shunt reactor current

再発弧が生じると、図 1 において、Cs〜1 $\sim S H \sim 1_{2} \sim C_{1}$. のループで高周波電流が流れる。電源からも負荷電流、才 な⿰ち負荷のリアクトルへ商用周波電流が流れる。従って、 開閉器には負荷電流と高周波電流の重盢した電流が流れ
る。図 2 はこれらの電流の様子を示している。再発弧㣪、 高周波電流に雾点（P1、P2 …)が作られる。しかし、高周 波電流は減衰し、負荷電流は增大するので、やがて高周波 電流の零点は発生しなくなる。これらの過程で、高周波電 流重鲳による電流零点で開閉器が遮断する場合がある。こ れを高周波消弧と言っている。SF6 ガス旗断器の場合、高 周波消弧怯、図 2 の P5 亿示されているような、高周波電 流の波高值が需線に接した時に発生寸る場合が多い[2]。

高周波消弧が発生すると、再発弧之高周波消弧を繰り返

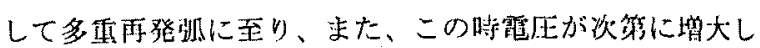
[1] [2]、機器の絶縁を脅か-す過電圧となる場合がある。

\section{3. 再発弧サージの計算}

\section{1 再発弧サージの計算回路}

高周波消弧の発生は、高周波電流の周波数に大きく传存 する。実際の $500 \mathrm{kV}$ 変電所における、シャントリアクトル 電流遮断時の再発弧高周波電流の周波数について、EMTP 用いて計算を行った。

図 3 は $500 \mathrm{kV}$ 変電所の例を模擬した計算回路である。 GIS、ケーブルは分布定数線路で模擬した。ケーブルは整 合抵抗にて終端した。変圧器は集中定数のキャパシタンス とした。シャントリアクトルは文献[7]の高周波用モデル で、油絶縁用の定数を用いた。

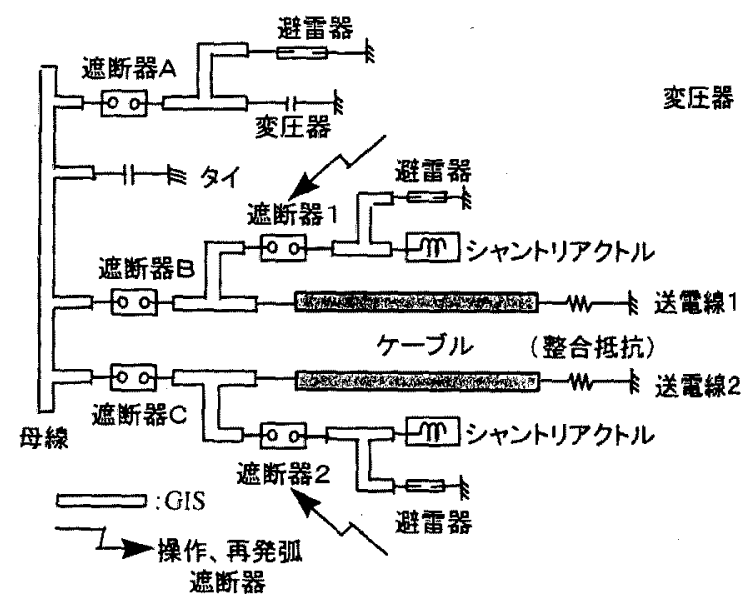

図 $3500 \mathrm{kV}$ 変電所の再発弧サージ計算回路

Fig. 3 Calculation circuit for re-ignition surges at a $500 \mathrm{kV}$ sub-station

\section{2 再発㢫時の高周波電流およびサージ過電圧}

図 3 において、遮断器 1 を操作して、再発弧した時の計 算波形を図 4 に示す。この時、他の遮断器 A、B、C、2 に ついては、すべて閉状態とし、すなわち、全回線接続状態 とした。図 4(a)は遮断器のリアクトル側端子電圧、(b)は (a)の再発根時点の搪大、(c)はリアクトル端子電压、(d) は同拡大である。(e)は遮断器 1 を流れる高周波電流であ って、その波高値が電流零線と接する付近を示す。 
図 4(a)に示すように、リアクトルを流れる商用周波電流 を一時遮断した後、遮断器のリアクトル側端子には、リア クトルの振動による電圧が現れている。その周波数は $1.53 \mathrm{kHz}$ であった。リアクトル電流の一時遮断後、リアク トル電圧が反転してピーク值となった時点 $\mathrm{P}$ 、才なわち、 遮断器 1 の極間電圧が最大となった時点において、遮断器 1 を再び閉じることで、再発弧を模擬した。

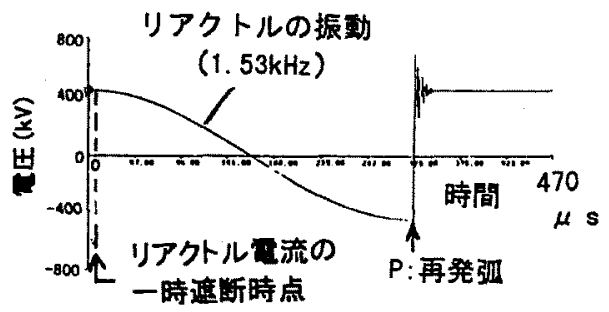

(a) 遮断器リアクトル傊端子電圧

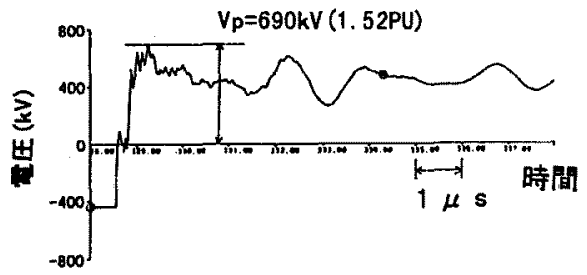

(b) (a)のP点付近の時間拡大

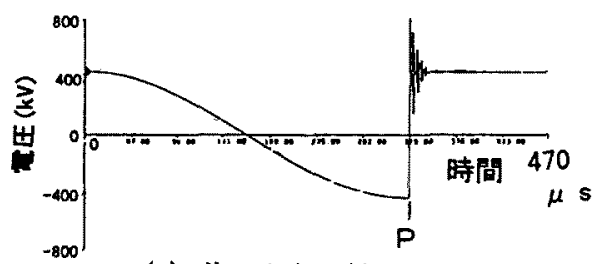

(c) リアクトル端子電圧

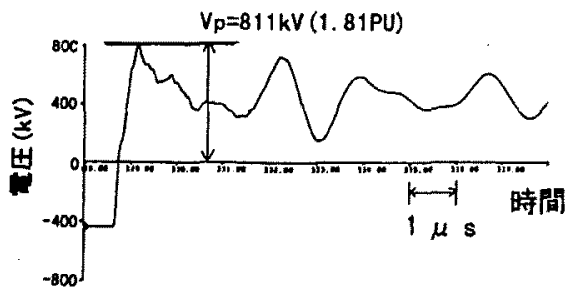

(d) (c)のP点付近の時間扩大

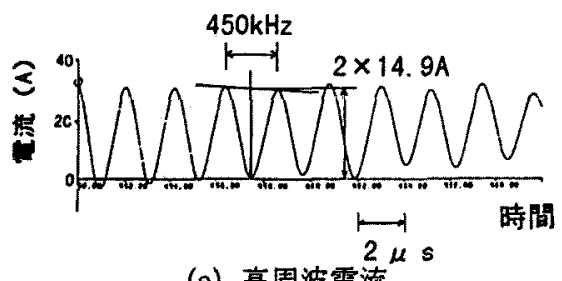

(e) 高周波電流

図 $4500 \mathrm{kV}$ 変電所の再発弧サージ計算波形例 Fig. 4 Example of calculation result of re-ignition surge at $500 \mathrm{kV}$ sub-station
図 4 のケースでは、高周波電流は図(e)に示すように、 周波数が $450 \mathrm{kHz}$ であった。再発弧時の過電圧は、リアク トル端子では、1.81p.u. (1p.u. $=449 \mathrm{kV})$ となった。

図 3 において、他の回路構成についても計算を行った。 計算結果をまとめて、図 4 の結果と併せて表 1 に示す。い ずれのクースにおいても、リアクトル電流の一時遮断後の リアクトル側端子電圧の周波数は約 $1.5 \mathrm{kHz}$ であった。再 発弧時の高周波電流の周波数は回線の接続状態によって 変化する。模擬した変電所では、290kHz〜 450kHzであった。 再発弧過電圧は全回線接続の条件が最も大きく、リアクト ル端子において、1.81p.u.であった。

表 1 部算結果

Table I Calculation results

\begin{tabular}{|c|c|c|c|c|c|}
\hline 지 & $\begin{array}{l}\text { 操 } \\
\text { 作 } \\
\text { 遮 } \\
\text { 断 } \\
\text { 器 } \\
\end{array}$ & 回路嚅成 & 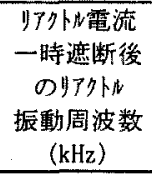 & $\begin{array}{l}\text { 再発弧時の } \\
\text { 颀快端子 } \\
\text { 電圧最大值 } \\
(\mathrm{kV})(\mathrm{p} . \mathrm{u} \text { ) }\end{array}$ & $\begin{array}{c}\text { 高周波 } \\
\text { 電流 } \\
\text { 周波数 } \\
(\mathrm{kHz})\end{array}$ \\
\hline 1 & 1 & 全回線接続 & 1.53 & $811 \quad 1.81$ & 450 \\
\hline 2 & 1 & 遮断器 $\mathrm{A}$ 開 & 1.55 & $802 \quad 1.79$ & 430 \\
\hline 3 & 2 & 遮断器 B 開 & 1.55 & $\begin{array}{ll}760 & 1.69\end{array}$ & 450 \\
\hline 4 & 1 & 遮断器 C 開 & 1.53 & $\begin{array}{ll}775 & 1.73\end{array}$ & 450 \\
\hline 5 & 2 & 遮断器 $A 、 B$ 開 & 1.55 & $\begin{array}{ll}759 & 1.69 \\
\end{array}$ & 290 \\
\hline 6 & 1 & 遮断器 A、C 開 & 1.53 & $760 \quad 1.69$ & 300 \\
\hline
\end{tabular}

\section{4. 遮断器の高周波消弧特性}

\section{1 試験回路および高周波電流測定方法}

$550 \mathrm{kV}$ 一点切りガス遮断器を用いて、リアクトル電流遮 断試験を行った。再発弧の際の高周波消弧特性を測定した。 試験回路を図 5 に示す。短絡発電機を電源とし、電圧は $550 / \sqrt{\mathrm{kV} V}$ とした。2.65H の空心リアクトル $\mathrm{L}$.を用意して、 これに流れる電流 $380 \mathrm{~A}$ を、 $550 \mathrm{kV}$ 一点切りガス遮断器 $\mathrm{CB}$ で遮断した。

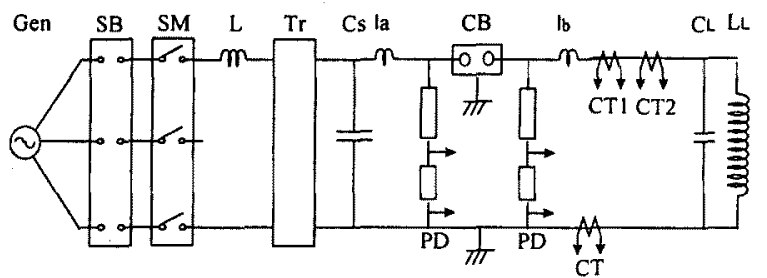

Gen:短絡発電機、SB: 保裂遮断器、SM: 投入開開器 $\mathrm{Tr}$ : 試験用变压器、 $\mathrm{la} 、 \mathrm{lb}$ : 高周波電流調整用りアクトル。 Cs:電源側コンデンサ, CT: 変流器, PD: 分圧器

$\mathrm{CL}$ : 負荷側静電容量。 $\mathrm{LL}$ : 空心リアクトル CT1、CT2:高周波電流測定用变流器、 $\mathrm{CB}: 550 \mathrm{kV}$ 一点切りガス㵂断器

図 $5550 \mathrm{kV}$ シャントリアクトル電流遮断試験回路

Fig. 5 Test circuit of $550 \mathrm{kV}$ shunt reactor current interruption 
リアクトル電流一時遮断後の遮断器負荷側の電圧振動 の周波数は、図 5 の試験回路において、空心リアクトル $\mathrm{L}_{\mathrm{L}}$ と負荷側静電容量 $C_{\mathrm{L}}$ によって決まる。この周波数が高いほ ど、一般に再発弧は発生しやすい。実際の変電所では、 $C_{\mathrm{L}}$ は主として、遮断器とリアクトルの間の線路及びリアクト ル自身の静電容量である。実際の変電所において、C さい場合を想定して、試験では、 $1.8 \mathrm{kHz} 、 2.5 \mathrm{kHz}$ とした。 再発弧の際にリアクトル端子に大きな過電圧が発生する ように、Cs の静電容量の值を $C_{L}$ の約 10 倍にした[8]。再発 弧の際の高周波電流は Cs-1a-CB-1b-C の回路で流れる。1a、 lb の値を変化させて、高周波電流の周波数を $26 \sim 170 \mathrm{kHz}$ に変化させた。

遮断器 $\mathrm{CB}$ に流れる高周波電流を精度よく測定するため に、高電圧の遮断器端子に 2 つの変流器 CT1、CT2 を設置 した。CT1 は高周波電流全体の測定用である。CT2 は高周 波電流零点近傍の小さな信号測定用として、出力にダイオ ードクリッパを接続した[2]。CT1、CT2 の出力信号は高電 圧側で $\mathrm{E} / 0$ 変換器を用いて光信号に変換し、光ファイバー でアース電位の測定点まで伝送した。

図 6 は $550 \mathrm{kV}$ シャントリアクトル電流遮断試験の状況を 示す。

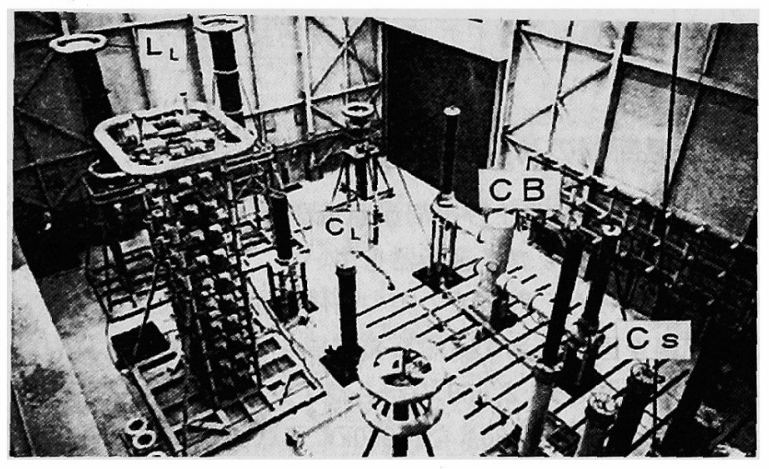

図 $6500 \mathrm{kV}$ シャントリアクトル遮断試験状況

Fig. 6 View of $550 \mathrm{kV}$ shunt reactor current interruption test

\section{2 高周波消弧特性}

図 7 に測定結果のオシログラム例を示す。遮断器が $Q$ 点 で開極を始めた後、最初の電流零点 $\mathrm{R}$ で一時的に電流を遮 断し、その直後に再発弧が発生している。再発弧の発生後、 再び商用周波電流が流れて、S 点で遮断が完了している。

図 8 は、図 7 の再発弧時点 $\mathrm{R}$ 付近の遮断器負荷側端子電 圧波形の払大である。図 7 の波形を得た測定器とは別の測 定器によって得た。電流遮断後、リアクトル $\mathrm{L}_{\mathrm{L}}$ と $\mathrm{C}_{\mathrm{L}}$ による 約 $2.5 \mathrm{kHz}$ の電圧振動が現われている。その後、再発弧が 生じ、周波数約 $120 \mathrm{kHz}$ の電圧振動の再発弧サージが発生 している。

図 7 の再発弧時点の高周波電流の波形を図 9 に示す。図 9 (a) は、CT1 を用いて測定したオシログラムである。図 9(b)
は、クリッパを設けた CT2 を用いて測定したオシログラム であって、再発弧発生から約 $90 \mu \mathrm{s}$ 間は、高周波電流の 波高值はクリップされている。図 9(c) は、図 9(b) の区間 T の拡大波形である。高周波電流の周波数は $120 \mathrm{kHz}$ である。

高周波消弧は、電流零点での電流の傾き $\mathrm{di} / \mathrm{dt}$ が小さい 時に発生しやすい。di/dt が最小となるのは、図 9(c)のA 点に示すように、高周波電流の波高値が雾線に接する時で ある。図 $9(\mathrm{c})$ のオシログラムは、この $\mathrm{A}$ 点においても高周 波消弧が発生していないことを示している。A 点において 高周波消弧しなければ、以降惊周波電流によって電流零 点が作られることはないので、もはや高周波消弧は発生せ ず、再び商用周波電流が流れつづけることになる。この商 用周波電流は、次の商用周波電流零点において遮断される。

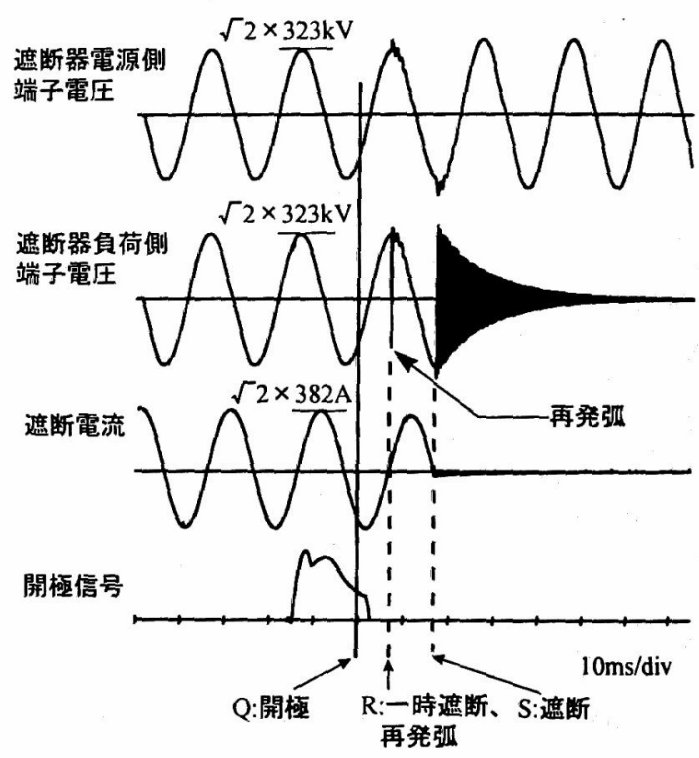

図 7 遮断試験結果オシログラム例

Fig. 7 Example of oscillograms obtained at test

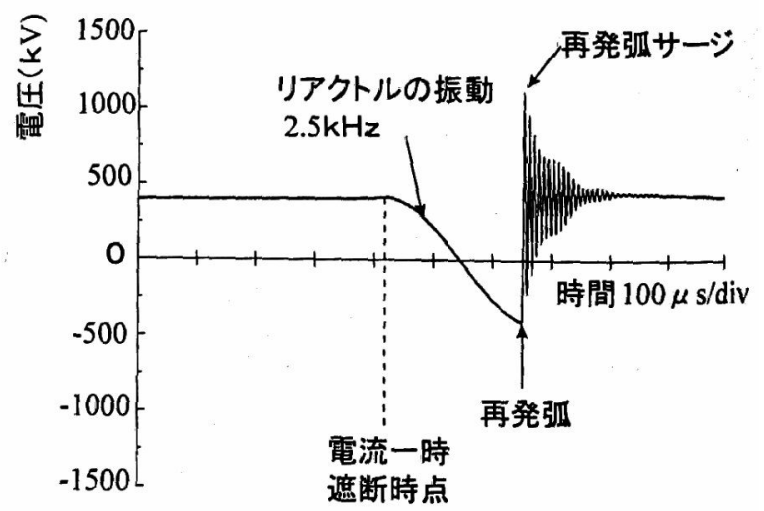

図 8 図 7 における再発弧時点の遮断器負荷側端子 電圧波形拡大

Fig. 8 Enlarged waveform of the load side terminal voltage at re-ignition 


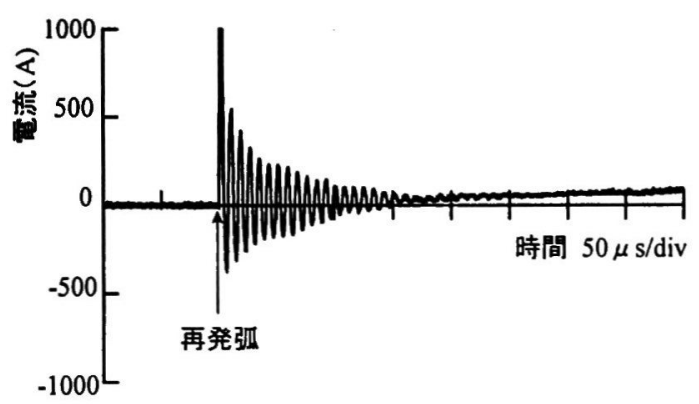

(a) CT1 のオシログラム

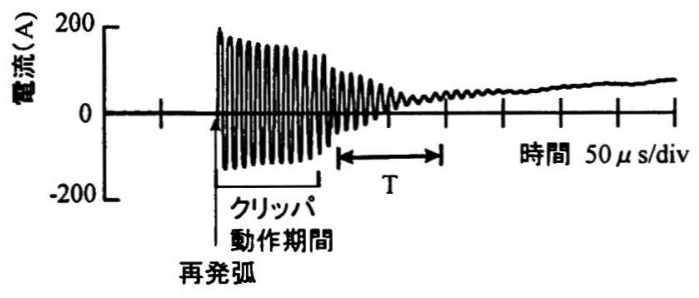

(b) CT2(クリッパ付き)のオシログラム

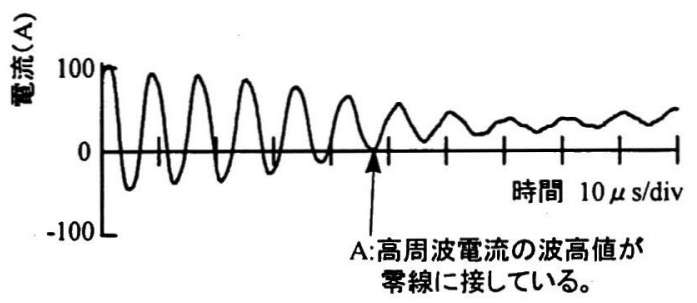

(c) (b) の区間 T の拡大波形

図 9 高周波電流の測定波形 : $120 \mathrm{kHz}$

Fig. 9 High-frequency current waveform obtained by measurement : $120 \mathrm{kHz}$

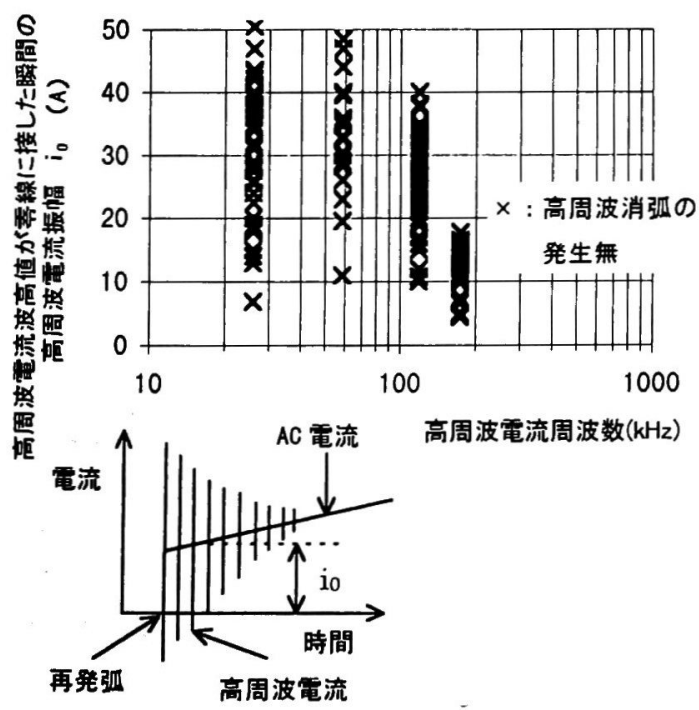

図 10 高周波消弧特性の測定結果のまとめ

Fig. 10 Test results of high-frequency arc extinction
高周波電流の周波数を変えて行った、高周波消弧につい ての試験結果をまとめて図 10 に示す。図 10 の縦軸の $\mathrm{i}_{0}$ は、高周波電流波高値が零線と接した瞬閒の高周波電流振 幅を示したものである。 $i_{0}$ の值は、再発弧の発生時点によ って異なり、従って、試験ごとに異なる。 $\mathrm{i}_{0}$ が小さいほど 高周波消弧は発生しやすい[3]。図 10 は、高周波電流の周 波数 $170 、 120 、 59 、 26 \mathrm{kHz}$ いずれにおいても、高周波消弧 は発生しなかったことを示している。各周波数において、 高周波電流波高值が零線に接した場合、即ち $\mathrm{di} / \mathrm{dt} \fallingdotseq 0$ で も、高周波消弧は発生しなかった。

\section{3 フィールドでの高周波消弧発生有無の評価}

高周波電流の周波数が低いほど高周波消弧は発生しゃ すくなると考えられる $[4]$ 。3 章の実際の変電所を模擬した 再発弧サージ計算結果では、 $290 \mathrm{kHz}$ が最も低い周波数であ った。しかし、今回の試験では、図 10 に示すように、 $26 \mathrm{kHz}$ まで高周波電流の周波数を下げても高周波消弧は発生し なかった。この試験結果から、 $550 \mathrm{kV}$ 一点切り遮断器は実 際の変電所では高周波消弧せず、多重再発弧による高いサ ージ電圧の発生等はないものと考えられる。

\section{4 高周波消弧の発生におけるガスの吹き付けの影響} $550 \mathrm{kV}$ 一点切り遮断器では、前述のように、高周波電流 の周波数を $26 \mathrm{kHz}$ まで下げても、高周波消弧は発生しなか った。一方、文献[2]では、300kV 遮断器において、図 11 に示すように、高周波電流周波数 $52 \mathrm{kHz}$ にて、高周波消弧 を観測したことを報告している。

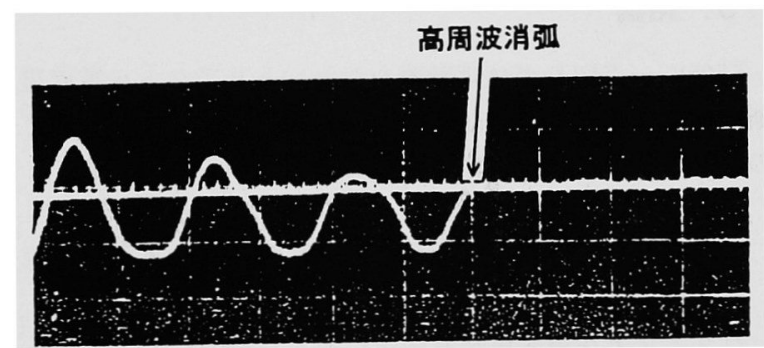

横軸: 時間、 $10 \mu \mathrm{s} / \mathrm{div}$

絿軸 : 電流、100A div

図 11 高周波消弧の発生を示寸高周波電流 オシログラム例[2]

Fig. 11 Example waveform of high frequency current showing high-frequency arc extinction[2]

SF6 ガス遮断器はパッファシリンダ内でガスを圧縮し、 アークに吹き付けることで消弧する。シャントリアクトル 電流遮断時に再発弧が生じるのは、開極初期の極間距離が 短い時間領域である。図 12 は、用いた $550 \mathrm{kV}$ 一点切り遮 断器の消弧室の、開極初期におけるガスの吹き付けの様子 を示している。図 12 において、吹き出し穴が短絡大電流 の遮断性能の向上を目的として、パッファシリンダ部に位 
置している[9]。しかし、リアクトル電流は小電流であっ て、従って、ガス流 1 とこの吹き出し穴からガス流 2 が接 触子間に点弧したアークに向って発生しようとする。しか し、これらのガス流は、開極初期において、固定接触子と ノズルにはばまれてほとんど発生しない。

これに対して、文献[2]におけるガス遮断器では、図 12 における吹き出し穴が、ピストンの右側に位置して、外部 に連通していた。このため、ガス流 2 が存在せず、しかし、 ガス流 1 は吹き出し穴に向って形成される。このため、開 極初期におけるアークへの吹き付けガス流は、今回の $550 \mathrm{kV}$ 一点切りガス遮断器のほうが弱いと思われる。これ が上記の高周波消弧特性の差の主な原因と思われる。高周 波消弧の発生に対する過渡回復電圧の影響については、小 さいことが文献 $[4]$ に述べられている。

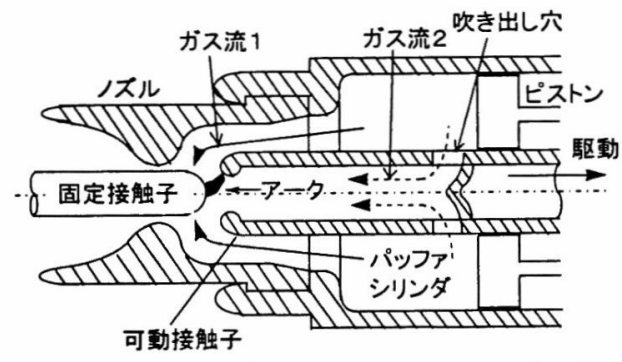

図 $12550 \mathrm{kV}$ 一点切り遮断器の開極初期のガス流の様子

Fig. 12 Gas flow of $550 \mathrm{kV}$ one-break GCB at initial stage of opening

\section{5. 結論}

$550 \mathrm{kV}$ 一点切りガス遮断器をシャントリアクトル電流遮 断に適用するため、再発弧の際の高周波消弧特性について の検討を行った。本論文をまとめると次のようになる。

1) $500 \mathrm{kV}$ 変電所を模擬して、リアクトル電流遮断時の再 発弧サージ計算を行った。再発弧時の際の高周波電流 周波数は、 $290 \mathrm{kHz}$ 以上であった。

2) リアクトル電流遮断試験を行って、550kV一点切りガ ス遮断器の高周波消弧特性を測定した。試験において、 高周波電流周波数を $26 \mathrm{kHz}$ にまで下げても、高周波消 弧は発生しなかった。

3) 高周波消弧は、高周波電流の周波数が低いほど発生し やすい。上記 1)、2) から、 $550 \mathrm{kV}$ 一点切りガス遮断器 を実際の変電所において、シャントリアクトル電流遮 断に適用しても、高周波消弧は発生しないものと考え られる。従って、多重再発弧による高いサージ電圧の 発生はないものと考えられる。

(平成 11 年 3 月 5 日受付、同 11 年 7 月 15 日再受付)

文 献

[1] 電気学会技術報告（II 部）第 388 号

「大容量遮断器の特殊遮断条件」
[2] H. Kawada, K. Goto, M. Hanamura, S. Yanabu, S. Nishiwaki, T. Ueda, Y. Murayama "Switching Surge of Shunt Reactor caused by SF6 Circuit Breaker Operation" IEEE Trans. on Power Delivery Vol.2, No. 4 pp. 1124-1130 1987

[3] E. Zaima, S. Okabe, S. Nishiwaki, M. Ishikawa, T. Nakamoto, Y. Murayama, Y. Kawaguchi "Reignition Surges at Reactor Current Interruption in Cable-system GIS" IEEE Trans. on Power Delivery Vol. 5, No. 2, pp. 947-954 1990

[4] E. Zaima, S. Okabe, S. Nishiwaki, M. Ishikawa, K. Suzuki, H. Toda "Application of Dynamic Arc Equations to High-Frequency Arc Extinctions in SF6 Gas Circuit Breakers" IEEE Trans. on Power Delivery Vol. 8, No. 3, pp. 1199-1205, 1993

[5] 山形、熊谷、西脇、戸田、石川、横田 「ガス遮断器の開極位相制御によるシャントリアク トル電流遮断に伴う再発弧過電圧の抑制」 電気学会 論文誌 B、112 巻 2 号、pp. 161-167 平成 4 年

[6] D. F. Peelo, E. M. Ruoss " A New IEEE Application Guide for Shunt Reactor Switching" IEEE PES Summer Meeting 95SM607-2 PWRD 1995

[7] 岡部、向當、寺西、石川、小林、才田 「ガス絶縁シャントリアクトルの高周波サージ解析 用電気モデル」 電気学会 電力・エネルギー論文誌、 117 巻 5 号、 pp. 700-705 平成 9 年

[8] IEC1233 Technical Report "High-voltage alternating current circuit-breakers Inductive load switching" 1994

[9] S. Yanabu, H. Mizoguchi, H. Ikeda, K. Suzuki, M. Toyoda " Development of Novel hybrid Puffer Interrupting Chamber for SF6 Gas Circuit Breaker utilizing Self-Pressure-Rise Phenomena by Arc" IEEE Trans. Power Delivery, Vol. 4, No. 1, pp. $355-361,1989$

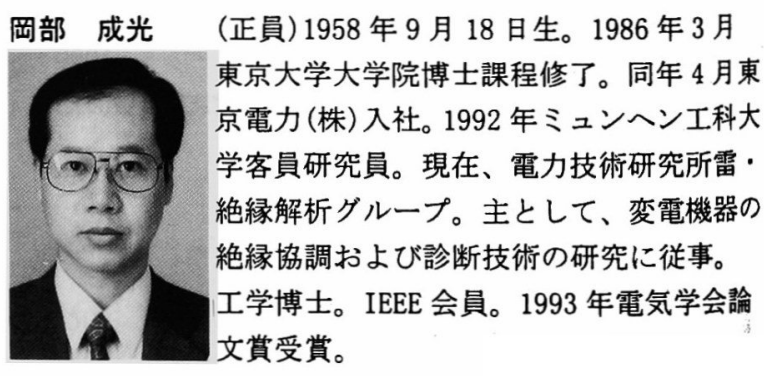



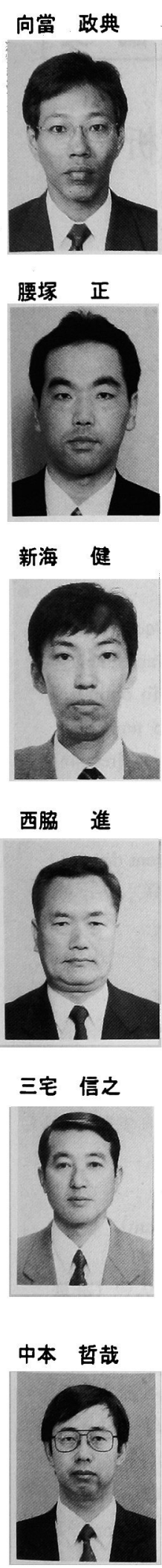

（正員）1947年 1 月 3 日生。1969 年 3 月 横浜国立大学工学部卒業。同年 4 月 (株) 東 芝入社。サージ現象、避雷器、開閉保護装 置などの研究開発に従事。工学博士。 昭和 58 年、平成 5 年電気学会論文賞受賞。 IEEE 会員。

（正員）1947年 6 月 10 日生。1968 年 3 月 久留米工業高等専門学校電気工学科卒業。 同年 4 月、（株）東芝入社。主として遮断 器の合成試験法の開発、送変電機器の開発 に従事。1998 年電気学会論文賞受賞。

（正員）1957年 2 月 4 日生。1981年 3 月 京都大学大学院電気工学専攻修士課程修 了。同年 4 月（株）東芝入社。以来、ガス遮 断器の開発・設計に従事。平成 5 年電気学

会論文賞受賞。

(正員) 1965 年 6 月 29 日生。1992 年 3 月 東京電機大学大学院工学研究科修士課程 修了。同年 4 月 (株) 東芝入社。現在、電力. 産業システム技術開発センター。開閉保護 装置の研究開発に従事。IEEE 会員。

早稲田大学理工学研究科修士課程修了。同 年 4 月、（株）東芝入社。以来、ガス遮断 器の開発及び遮断現象の研究に従事。

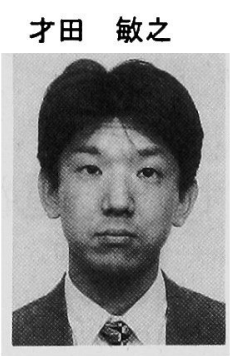

(正員) 1967年1月12日生。1991年3月名古屋 大学大学院電気工学専攻修士課程修了。同 年 4 月（株）東芝入社。同社電力变電技術 部において, 主として変電プラントのシス テムエンジニアリングに従事。 